\title{
Effects of lidocaine associated with detomidine on sedation of horses undergoing dental procedures
}

\section{Efeitos da lidocaína associada a detomidina na sedação de equinos submetidos a procedimentos odontológicos}

\author{
Samuel Jorge Ronchi ${ }^{1 *}$; Amarildo Oliveira Lyra de Souza ${ }^{2}$; Felipe Comassetto ${ }^{1}$; \\ Karen Suzane Fuchs ${ }^{2}$; Luara Da Rosa ${ }^{1}$; João Ricardo Kunz²; Joandes Henrique \\ Fonteque $^{3}$; Ademir Cassiano da Rosa ${ }^{3}$; Nilson Oleskovicz ${ }^{3}$
}

\section{Highlights:}

The association between detomidine and lidocaine reduced the required dose of detomidine. Cardiovascular changes were observed even with a low detomidine dose.

Lidocaine use was ineffective in reducing the intestinal hypomotility caused by detomidine.

\begin{abstract}
Due to the growing increase in the dental routine in equine medicine, along with the need for patient sedation to perform this procedure, this study aimed to assess sedation by detomidine alone and/or associated with lidocaine under continuous infusion. Twenty-two horses from the dental routine of the veterinary hospital of the institution of origin were used. A jugular catheter was implanted on the day of study and animals were allocated into two distinct groups $(\mathrm{n}=11)$ : GD, which received detomidine $(20 \mu \mathrm{g}$ $\left.\mathrm{kg}^{-1}\right)$, followed by continuous infusion $\left(20 \mu \mathrm{g} \mathrm{kg}^{-1} \mathrm{~h}^{-1}\right)$; and GDL, animals which received detomidine $\left(10 \mu \mathrm{g} \mathrm{kg}^{-1}\right)$ and lidocaine $\left(1.3 \mathrm{mg} \mathrm{kg}^{-1}\right)$, followed by continuous infusion of detomidine $\left(10 \mu \mathrm{g} \mathrm{kg}^{-1} \mathrm{~h}^{-1}\right)$ and lidocaine $\left(25 \mu \mathrm{g} \mathrm{kg}^{-1} \mathrm{~min}^{-1}\right)$. The assessed moments were as follows: M0, before catheter placement; M1, 5 minutes after bolus and beginning of infusion; M2, placement of mouth speculum; and M3, wear with an electric rasp. The assessed parameters were heart rate (HR), respiratory rate $(f)$, systolic blood pressure (SBP), and intestinal motility. In addition to the clinical parameters, sedation was assessed by measuring head height in relation to the ground before (M0) and after treatment administration (M1) and during the dental procedure using a scale adapted for dental procedures. Statistical analysis was performed using the Shapiro-Wilk normality test by applying one-way RM ANOVA, followed by the Dunnett test for comparison in relation to M0, t-test, and Mann-Whitney test between groups ( $\mathrm{p} \leq$ 0.05 ). HR decreased by $20 \%$ at M2 and M3 compared to M0 only in GD, while SBP increased 35\% at the same moments compared to M0 in GD and 27, 42, and 27\% at M1, M2, and M3 compared to M0 in GDL, respectively. Intestinal motility decreased by $75 \%$ at all moments compared to M0 in both groups. Head height decreased by $67 \%$ in GD and $60 \%$ in GDL, with no difference between groups. Sedation scores provided by the scale did not differ between groups, with values of 1 [0-3] in GD and 3 $[0-4]$ in GDL at M2 and 1 [0-3] in GD and 1 [1.5-3] in GDL at M3. Thus, sedation by the association between detomidine and lidocaine allowed reducing detomidine dose in half but offering similar results for dental procedures.
\end{abstract}

Key words: Sedation. Local anesthetic. $\alpha-2$ agonist. Equine dentistry.

\footnotetext{
${ }^{1}$ Discentes, Curso de Doutorado do Programa de Pós-Graduação em Ciência Animal, Centro de Ciência Agroveterinárias, Universidade do Estado de Santa Catarina, UDESC, SC, Brasil. E-mail: samuelronchi@yahoo.com.br; felipecomassetto@ yahoo.com.br; luh-rosamona@hotmail.com

2 Médicos Veterinários Autônomo, Florianópolis, SC, Brasil. E-mail: amarildo.ols@hotmail.com; karensuzane@hotmail.com; kunz.vet@hotmail.com

3 Profs. Drs., Departamento de Medicina Veterinária, Centro de Ciência Agroveterinárias, UDESC, SC, Brasil. E-mail: joandes. fonteque@udesc.br; ademir.rosa@udesc.br; noleskovicz@yahoo.com.br

* Author for correspondence
} 


\section{Resumo}

Devido ao crescente aumento da rotina odontológica na medicina equina, juntamente com a necessidade de sedação dos pacientes para a realização destes procedimentos, objetivou-se avaliar a sedação promovida pela detomidina isolada e, ou, associada com lidocaína sob regime de infusão contínua. Foram utilizados 22 equinos provindos da rotina odontológica do hospital veterinário da instituição de origem. No dia do estudo, foi implantado um cateter na jugular, alocando-se os animais em 2 grupos distintos $(\mathrm{n}=11)$ : $\mathrm{GD}$, os quais receberam detomidina $\left(20 \mu \mathrm{g} \mathrm{kg}^{-1}\right)$ seguido de infusão contínua (20 $\left.\mu \mathrm{g} \mathrm{kg}^{-1} \mathrm{~h}^{-1}\right)$; GDL, os quais receberam detomidina $\left(10 \mu \mathrm{g} \mathrm{kg}^{-1}\right)$ e lidocaína $\left(1,3 \mathrm{mg} \mathrm{kg}^{-1}\right)$, seguido de infusão contínua de detomidina $\left(10 \mu \mathrm{g} \mathrm{kg}^{-1} \mathrm{~h}^{-1}\right)$ e lidocaína $\left(25 \mu \mathrm{g} \mathrm{kg}^{-1} \mathrm{~min}^{-1}\right)$. Os momentos avaliados foram: M0, antes da colocação do cateter; $\mathrm{M} 1,5$ minutos após o bolus e início da infusão; $\mathrm{M} 2$, no momento da colocação do abre bocas; M3, momento do desgaste com a grosa elétrica. Os parâmetros avaliados foram: frequência cardíaca (FC), frequência respiratória $(f)$, pressão arterial sistólica (PAS) e motilidade intestinal. Além dos parâmetros clínicos, foi avaliada a sedação medindo-se a altura de cabeça em relação ao solo antes (M0) e após a administração dos tratamentos (M1), assim como durante o procedimento odontológico através de uma escala adaptada para procedimentos odontológicos. A análise estatística foi realizada através do teste de normalidade Shapiro-Wilk, aplicando-se One Way RM ANOVA seguido por Dunnet para comparação em relação ao M0, teste de t e Mann-Whitney entre grupos $(\mathrm{p} \leq 0,05)$. A FC reduziu $20 \%$ no M2 e M3 em relação ao M0 somente no GD, já a PAS aumentou $35 \%$ nos mesmos momentos em relação ao M0 no GD e no M1, M2 e M3 do GDL também houve um aumento de $27 \%, 42 \%$ e $27 \%$, respectivamente, em relação ao M0. A motilidade intestinal reduziu $75 \%$ em todos os momentos em relação ao M0 em ambos os grupos. A altura da cabeça diminuiu $67 \%$ no GD e $60 \%$ no GDL, sem diferença entre os grupos. Os escores de sedação fornecidos pela escala não diferiram entre os grupos, sendo este no M2 de 1 [0 - 3], no GD, e 3 [0 - 4], no GDL, e no M3, no GD 1 [0 - 3], e 1 [1,5 - 3], no GDL. Conclui-se que a sedação ofertada pela associação de detomidina e lidocaína reduziu a dose de detomidina pela metade, oferecendo sedação similar para procedimentos odontológicos.

Palavras-chave: Sedação. Anestésico local. $\alpha-2$ agonista. Odontologia equina.

\section{Introduction}

Oral health is indispensable for the vitality, longevity, and performance of horses and, therefore, the administration of anesthetics for their sedation and comfort while performing dental procedures is essential. The use of $\alpha-2$ agonists for sedation in horses is well known due to their effectiveness. Detomidine is an example of such agents, with effects already reported in the literature (Nannarone, Gialletti, Veschini, Bufalari, \& Moriconi, 2007; Rohrbach, Korpivaara, \& Schatzmann, 2009; Valverde, 2010). However, these effects are relatively short (Rohrbach et al., 2009), and associations have been sought to enhance the offered sedation.

Detomidine associated with morphine or methadone for dental procedures has not intensified sedation compared to detomidine alone (Guilhen, Cassu, Diniz, Giuffrida, \& Duarte, 2015). Similarly, the association between lidocaine and xylazine has not potentiated xylazine sedation but increased the nociceptive threshold, measured by electrical stimulation (Souza, Monteiro, Campagnol, Ramos, \& Frasson, 2012). Although this association did not increase sedation, the authors used the maximum dose of xylazine, which may have caused a ceiling effect on sedation, and did not use any score to assess sedation, except for head height and response to clapping. Thus, the association between $\alpha-2$ agonist and lidocaine may be beneficial for dental procedures due to an increase in the nociceptive threshold.

In this sense, considering the scarce literature using the association between lidocaine and detomidine, this study aimed to assess the sedation in horses submitted to dental procedures promoted by the continuous infusion of detomidine alone or 
associated with lidocaine and using half the dose when it was associated with lidocaine. The impact of lidocaine on intestinal motility of horses submitted to detomidine sedation was also assessed. The main hypothesis is that lidocaine will significantly reduce the detomidine dose without impairing the sedative score, besides softening motility reduction caused by the studied $\alpha-2$ agonist.

\section{Materials and Methods}

The study was submitted to the ethics committee and was approved under the number 2306170616. Twenty-two crossbred adult female horses, with a mean age of $15 \pm 3$ years and an indication of odontoplasty, coming from the hospital routine of the institution of origin, were used in this experiment. Exclusion criteria consisted of changes in hematological and biochemical tests or the need for more invasive dental procedures, such as tooth extraction. All animals underwent a 12-hour fasting period.

A $14 \mathrm{G}$ venous catheter was inserted into the jugular vein before sedation and attached to a threeway faucet. Treatments were randomly selected, and patients were allocated into two groups $(n=11)$ : detomidine group (GD), in which animals received intravenous bolus of $20 \mu \mathrm{g} \mathrm{kg}^{-1}$ of detomidine, followed by continuous intravenous infusion of 20 $\mu \mathrm{g} \mathrm{kg}^{-1} \mathrm{~h}^{-1}$ of detomidine, and lidocaine-associated detomidinegroup(GDL), which received intravenous bolus of $10 \mu \mathrm{g} \mathrm{kg}^{-1}$ of detomidine associated with $2 \%$ lidocaine without vasoconstrictor at a dose of $1.3 \mathrm{mg} \mathrm{kg}^{-1}$, followed by intravenous infusion of $10 \mu \mathrm{g} \mathrm{kg}^{-1} \mathrm{~h}^{-1}$ of detomidine associated with $2 \%$ lidocaine without vasoconstrictor at a rate of 25 $\mu \mathrm{g} \mathrm{kg}^{-1} \mathrm{~min}^{-1}$. The required detomidine volume in GD was calculated for 1 hour, and the volume was completed with physiological solution up to $20 \mathrm{~mL}$, setting the flow rate of the syringe infusion pump to $20 \mathrm{~mL} \mathrm{~h}^{-1}$ and another separate pump with physiological solution at the same rate as lidocaine infusion used in GDL in order for the sedation evaluator to be blind to the treatments. Detomidine administration in GDL followed the same procedure as that in GD, but lidocaine was administered in a separate infusion pump with an estimated flow rate of $25 \mu \mathrm{g} \mathrm{kg}^{-1} \mathrm{~min}^{-1}$.

Clinical parameters consisted of assessing the heart rate (HR) by stethoscopy, respiratory rate $(f)$ by visualizing the rib cage, systolic blood pressure (SBP) by using a vascular Doppler positioned in the coccygeal artery and aneroid sphygmomanometer, and intestinal motility by auscultation and counting of borborygmi in the four quadrants (upper and lower right and left) for 30 seconds at each point, with its value corresponding to the sum of the complete movements of quadrants and, in case of uncoordinated or gas sounds, the score was only 0.5 (Mama, Grimsrud, Snell, \& Stanley, 2009). The degree of sedation consisted of using an adaptation of a specific scale to assess sedation in horses undergoing dental procedures (Roscoe, 2007). This scale was also used in a similar study (Guilhen et al., 2015). The periodontal sensitivity was removed for this adaptation due to the impossibility of the measurement during the dental procedure (Table 1). Head height in relation to the ground was also measured before (M0) and 5 minutes after (M1) treatment administration using a graduated scale in centimeters fixed to the side of the animal's body. The same experienced evaluator always performed the assessments of sedation and other parameters. In addition, a veterinarian experienced in equine dentistry also performed the dental procedure.

The assessed moments were before treatment administration and insertion of the jugular catheter (M0), 5 minutes after the bolus administration and beginning of continuous infusion(M1), when placing the mouth speculum (M2), and when wearing with an electric rasp (M3). Clinical parameters such as $\mathrm{HR}, f$, SBP, and intestinal motility were assessed at all these moments. Sedation was assessed only at moments corresponding to the stimuli performed by the veterinarian responsible for the procedure, being assessed only three items, namely: reaction to the 
mouth speculum, oral stimulation with water, and tongue tone at M2 and sound stimulus and wear with the electric rasp and tongue tone at M3. The sum of points on the sedation scale at both moments with these three criteria would reach a maximum score of 9 points, which corresponded to an animal without any sign of sedation, while 0 points corresponded to an animal without any reaction.

Table 1.

Sedation scale used in the study. Source: "Avaliação de seis protocolos para procedimentos odontológicos em equinos" (Roscoe, 2007)

\begin{tabular}{|c|c|c|}
\hline Type & Criterion used to assess the degree of sedation & Score \\
\hline \multirow{4}{*}{ Tongue tone } & Tongue relaxed and unresponsive to touch & 0 \\
\hline & Tongue relaxed and responsive to touch & 1 \\
\hline & Tongue relaxed and responsive to manual traction & 2 \\
\hline & Tongue with movement and reaction to manual traction & 3 \\
\hline \multirow{4}{*}{$\begin{array}{l}\text { Oral stimulation with } \\
\text { water }\end{array}$} & Absent reaction & 0 \\
\hline & Tongue movement & 1 \\
\hline & Tongue movement and chewing & 2 \\
\hline & Tongue movement, chewing, and head movement & 3 \\
\hline \multirow{4}{*}{$\begin{array}{l}\text { Reaction to mouth } \\
\text { speculum }\end{array}$} & Absent reaction & 0 \\
\hline & Presence of chewing and absence of repeated and/or sudden head movement & 1 \\
\hline & Presence of chewing and repeated and/or sudden head movement & 2 \\
\hline & Inability to stay with the mouth speculum & 3 \\
\hline \multirow{3}{*}{$\begin{array}{l}\text { Response to sound stim- } \\
\text { ulus with electric rasp }\end{array}$} & Absent reaction & 0 \\
\hline & Discreet reaction with ear movement & 1 \\
\hline & Intense reaction with ear and head movement & 2 \\
\hline \multirow{5}{*}{ Wear with electric rasp } & Absent reaction & 0 \\
\hline & Tongue movement & 1 \\
\hline & Tongue movement and chewing & 2 \\
\hline & Tongue movement, chewing, and head removal & 3 \\
\hline & Impossibility of wear with electric rasp & 4 \\
\hline
\end{tabular}

Statistical analysis was performed using the software GraphPad Prism 7.0, in which the data were subjected to the Shapiro-Wilk normality test and then analyzed using the one-way RM ANOVA, followed by the Dunnett test for differences between moments in relation to $\mathrm{M} 0$, and t-test for differences between groups among variables with normal distribution $(p \leq 0.05)$. The Mann-Whitney test was used for sedation variables for comparison between groups $(\mathrm{p} \leq 0.05)$.

\section{Results}

Animal mean weight was $438 \pm 23 \mathrm{~kg}$ in DG and $452 \pm 35 \mathrm{~kg}$ in GDL, while the mean procedure time was $63 \pm 12 \mathrm{~min}$ in DG and $69 \pm 9 \mathrm{~min}$ in GDL, with no difference between groups.

Regarding clinical parameters (Table 2), HR decreased by $20 \%$, and SBP increased by $35 \%$ at M2 and M3 in DG compared to M0. In GDL, SBP increased by 27,42 , and $27 \%$ at M1, M2, and M3, 
respectively, compared to $\mathrm{M} 0$, with no difference between groups (Table 2). Intestinal motility decreased by $75 \%$ in both groups from M1, with no difference between treatments when considering the moments (Table 2).
Regarding the parameters used to assess sedation, head height in relation to the ground reduced by $69 \%$ in GD and 60\% in GDL compared to M1, with no difference between groups (Figure 1). Finally, sedation scores showed no differences between groups, individually or in their sum of moments M2 and M3 (Table 3).

Table 2

Mean values and standard deviation of heart rate (HR), respiratory rate $(f)$, systolic blood pressure (SBP), and intestinal motility in sedated horses submitted to dental procedures with continuous infusion of detomidine (GD) or detomidine associated with lidocaine (GDL) at basal moment (M0), 5 min after bolus administration and beginning of infusion (M1), placement of mouth speculum (M2), and wear with electric rasp (M3)

\begin{tabular}{cccccc}
\hline Parameter & Group & M0 & M1 & M2 & M3 \\
\hline \multirow{2}{*}{ HR (bpm) } & GD & $40 \pm 9$ & $34 \pm 5$ & $32 \pm 5 \mathrm{~A}$ & $32 \pm 4 \mathrm{~A}$ \\
& GDL & $40 \pm 9$ & $35 \pm 8$ & $35 \pm 9$ & $36 \pm 7$ \\
\hline \multirow{2}{*}{$f(\mathrm{mpm})$} & GD & $16 \pm 6$ & $11 \pm 3$ & $13 \pm 4$ & $10 \pm 3$ \\
& GDL & $18 \pm 8$ & $13 \pm 4$ & $13 \pm 3$ & $13 \pm 3$ \\
\hline \multirow{2}{*}{ SBP (mmHg) } & GD & $110 \pm 23$ & $133 \pm 25$ & $148 \pm 32 \mathrm{~A}$ & $148 \pm 33 \mathrm{~A}$ \\
& GDL & $104 \pm 12$ & $132 \pm 14 \mathrm{~A}$ & $148 \pm 20 \mathrm{~A}$ & $132 \pm 22 \mathrm{~A}$ \\
\hline Motility & GD & $4 \pm 1$ & $1 \pm 0.5 \mathrm{~A}$ & $1.5 \pm 0.5 \mathrm{~A}$ & $1.5 \pm 1 \mathrm{~A}$ \\
(borborygmi) & GDL & $4 \pm 1$ & $1 \pm 1 \mathrm{~A}$ & $1 \pm 1 \mathrm{~A}$ & $1 \pm 1 \mathrm{~A}$ \\
\hline
\end{tabular}

Uppercase letters: difference in relation to basal moment (M0) after one-way RM ANOVA, followed by the Dunnett test ( $\mathrm{p} \leq 0.05$ ).

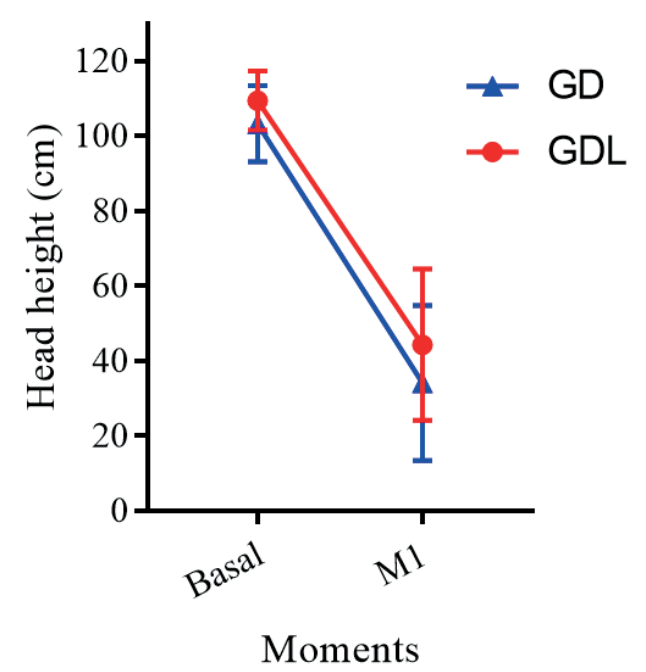

Figure 1. Mean value and standard deviation of head height in relation to the ground $(\mathrm{cm})$ before (M0) and 5 minutes (M1) after bolus and beginning of continuous infusion of detomidine (GD) or detomidine associated with lidocaine (GDL) in horses undergoing dental procedures. 
Table 3

Median, minimum, and maximum values of sedation and sum of scores at the moment of placing the mouth speculum (M2) and stimulation with electric rasp (M3) in horses undergoing continuous infusion of detomidine (GD) or detomidine associated with lidocaine (GDL) for performing dental procedures

M2

\begin{tabular}{ccccc}
\hline Group & Tongue tone & Reaction to mouth speculum & Oral stimulation with water & Summation \\
\hline GD & $0[0-2]$ & $0[0-0]$ & $1[0-3]$ & $1[0-3]$ \\
GDL & $1[0-2]$ & $0[0-1]$ & $1[0-3]$ & $3[0-4]$ \\
\hline \multicolumn{5}{c}{ M3 } \\
\hline Group & Tongue tone & Sound stimulus with electric rasp & Wear with electric rasp & Summation \\
\hline GD & $1[0-3]$ & $0[0-1]$ & $0[0-1]$ & $1[0-3]$ \\
GDL & $1[0-2]$ & $0[0-1]$ & $0[0-1]$ & $1[1,5-3]$ \\
\hline
\end{tabular}

\section{Discussion}

Changes in HR and SBP are well-known characteristics of $\alpha-2$ agonists, leading to a reduction in HR and a biphasic effect on BP, with an initial increase followed by a decrease in BP (Nannarone et al., 2007; Yamashita et al., 2000). It occurs because these drugs stimulate pre- and postganglionic $\alpha-2$ receptors by producing vasoconstriction and hence increasing BP and reducing HR by baroreflexes (Buhl, Ersbøll, Larsen, Eriksen, \& Koch, 2007). Moreover, $\alpha-2$ agonists are characterized by reducing sympathetic tone and increasing vagal tone (Buhl et al., 2007; Yamashita et al., 2000), making this reduction in HR even more marked.

These effects are dose-dependent, i.e., a 50\% lower detomidine dose in GDL would lead to side effects also lower, with no reduction in HR. However, both doses promoted an increase in SBP due to postganglionic $\alpha-2 B$ receptors stimulation, with no hypotensive effect because the continuous infusion of $\alpha-2$ was maintained over the study, remaining with the stimulation of $\alpha-2 \mathrm{~B}$ receptors. Another study comparing continuous infusion of xylazine $\left(1.1 \mathrm{mg} \mathrm{kg}^{-1} \mathrm{~h}^{-1}\right)$ with or without lidocaine (1.5 or $3 \mathrm{mg} \mathrm{kg}^{-1} \mathrm{~h}^{-1}$ ) showed no differences between groups regarding HR, possibly because xylazine dose was the same between groups (Souza et al., 2012), a fact that differed in the present study.
Also, the use of $\alpha-2$ agonists reduces intestinal motility in horses, which has been reported in in vitro (Zullian, Menozzi, Pozzoli, Poli, \& Bertini, 2011) and prospective studies (Elfenbein, Sanchez, Robertson, Cole, \& Sams, 2009). A retrospective study in horses undergoing colic surgery (Torfs, Delesalle, Dewulf, Devisscher, \& Deprez, 2009) showed that lidocaine infusion at a bolus dose of $1.3 \mathrm{mg} \mathrm{kg}^{-1}$ and continuous infusion at a rate of 3 $\mathrm{mg} \mathrm{kg} \mathrm{kg}^{-1}$ was associated with a low incidence of postoperative paralytic ileus. A similar study, in which horses with postoperative paralytic ileus had reflux (Malone et al., 2006), showed that $65 \%$ of patients receiving continuous infusion of lidocaine stopped reflux within 30 hours compared with only $27 \%$ of animals in the control group. Also, the authors reported that feces passage occurred within 16 hours after the beginning of lidocaine infusion, which was correlated with a positive response to the continuous infusion of lidocaine $(r=0.66)$.

As described above, thinking of lidocaine as a prokinetic agent is imperative. However, intestinal motility in horses undergoing continuous infusion of lidocaine (bolus of $1.3 \mathrm{mg} \mathrm{kg}$-1 followed by continuous infusion of $3 \mathrm{mg} \mathrm{kg}^{-1} \mathrm{~h}^{-1}$ ) was assessed through the duration of phases I, II, and III of the migratory myoelectric complex (MMC) and the number of phases III, showing no favorable results regarding lidocaine use compared to the 
placebo group, not corroborating that lidocaine has a prokinetic role (Milligan, Beard, Kukanich, Sobering, \& Waxman, 2007). These findings are similar to those described in the present study, in which the use of lidocaine was not effective in inhibiting the reduction of intestinal motility assessed by auscultation in patients receiving detomidine. A similarity between these studies is related to the use of $\alpha-2$ agonists in their protocol, as in the study cited above, besides xylazine, the authors also used ketamine and guaiacol glyceryl ether to place the electrodes and assess the intestinal motility thoroughly.

The mechanism by which lidocaine exerts the prokinetic effect is unknown, but the favorable results for its use as a prokinetic agent is related to its administration to patients with colic or some affection of the gastrointestinal system, mainly diseases that develop with inflammation, thus making its prokinetic effect a consequence of its anti-inflammatory effect (McCafferty, Sharkey, \& Wallace, 1994; Elfenbein et al., 2009; Torfs et al., 2009). Studies in which lidocaine promoted no prokinetic effect (Milligan et al., 2007), as well as the present study, used horses healthy from the gastrointestinal tract point of view, and their hypomotility is related to the use of drugs. The fact that lidocaine did not restore horse intestinal motility is a common result for both studies, as hypomotility is caused by drugs that reduce intestinal motility.

Head height in relation to the ground is a promising variable to assess sedation in horses. This variable allows numerically quantifying sedation, not being a subjective assessment, such as the case of using tables (Kaukinen, Aspegrén, Hyyppä, Tamm, $\&$ Salonen, 2010; Valverde, 2010). The continuous infusion of xylazine was assessed at a bolus dose of $0.55 \mathrm{mg} \mathrm{kg}^{-1}$ and continuous infusion rate of 1.1 $\mathrm{mg} \mathrm{kg}^{-1} \mathrm{~h}^{-1}$ associated with low $\left(1.5 \mathrm{mg} \mathrm{kg}^{-1} \mathrm{~h}^{-1}\right)$ or high lidocaine doses $\left(3 \mathrm{mg} \mathrm{kg}^{-1} \mathrm{~h}^{-1}\right)$, both infusions with bolus of $1.3 \mathrm{mg} \mathrm{kg}^{-1}$, showing that lidocaine did not potentiate xylazine sedation (Souza et al., 2012). However, sedation assessment was only the response to a sound stimulus (clapping) and head position in relation to the manubrium. Also, the electrical stimulation under the lateral palmar nerve in the thoracic limb led to a 190 and $158 \%$ increase in the nociceptive threshold in animals treated with low and high lidocaine doses, respectively, when compared to the basal, and $79 \%$ increase in the threshold of patients receiving xylazine alone (Souza et al., 2012).

The data from both the present study and the study cited in the previous paragraph are complementary, as the authors verified by a standard electrical stimulus that lidocaine in association with $\alpha-2$ agonist increases the nociceptive threshold. The present study consisted of a clinical study in which the stimulus was the wear with an electric rasp, sound stimulus, and other stimuli inherent to a dental procedure, being verified that the dose of the $\alpha-2$ agonist can be reduced when associated with lidocaine due to a synergistic effect of the used drugs, without impairing the procedure. Therefore, the reduction in response caused by lidocaine in the present study was verified clinically, as observed in a previous study (Souza et al., 2012), thus reducing the perception of the horse for the wear with the electric rasp and other stimuli inherent to the dental procedure.

The literature shows other studies assessing the association of $\alpha-2$ agonists with other drugs to perform dental procedures, in which the association between $10 \mu \mathrm{g} \mathrm{kg}^{-1}$ of detomidine and morphine or methadone, both at a dose of $0.1 \mathrm{mg} \mathrm{kg}^{-1}$, promoted a reduction of 44 and $41 \%$ in head height, respectively. This reduction was lower than that observed when using detomidine alone, which presented a $70 \%$ reduction (Guilhen et al., 2015), a value similar to that found in the present study for GD and GDL. The authors used the same assessment scale as the present study, with lower scores than the basal from 5 to $30 \mathrm{~min}$ after treatment administration, with no differences between scores in relation to basal after 30 minutes (Guilhen et al., 2015). Such difference can be attributed to the form of administration, as 
the previous study used single bolus and the present study administered drugs in continuous infusion, with no reduction in sedation scores over time. They stated that all animals allowed the study to be completed without additional drugs.

A reduction in the summation of the total score in both groups was observed between M2 and M3, with a detomidine dose $50 \%$ lower in GDL. Sedation scores and head height showed no difference between groups probably because lidocaine can reduce the detomidine dose required to perform anesthetic procedures. However, despite this nonstatistical difference, animals from GDL were more responsive to oral stimulation with water, which was assessed only at M2, and the total sedation score at M2 was higher than at other moments when considering this criterion for sedation assessment.

The assessment of intestinal motility by auscultation of intestinal borborygmi (Mama et al., 2009) was a limitation of the present study. It was only a clinical assessment of motility and not a complete assessment of it, as have been performed in other studies (Milligan et al., 2007), which assessed the jejunum electrical activity. Therefore, the information regarding the effects of lidocaine on the intestinal motility of healthy horses undergoing dental procedures sedated with continuous infusion of detomidine should be assessed in future studies. Also, another limitation of this study was the noncorrection of SBP values in relation to the heart base. However, because it occurred for all animals and the focus of the study was the degree of sedation, the authors believe that this fact does not make the results and conclusions found in the present study unfeasible.

\section{Conclusion}

Bolus lidocaine, followed by continuous infusion, reduces the required detomidine dose for sedation of healthy horses undergoing dental procedures. However, it was not effective in inhibiting the reduction in the intestinal motility caused by detomidine.

\section{References}

Buhl, R., Ersbøll, A. K., Larsen, N. H., Eriksen, L., \& Koch, J. (2007). The effects of detomidine, romifidine or acepromazine on echocardiographic measurements and cardiac function in normal horses. Veterinary Anaesthesia and Analgesia, 34(1), 1-8. doi: 10.1111/j.1467-2995.2005.00269.x

Elfenbein, J. R., Sanchez, L. C., Robertson, S. A., Cole, C. A., \& Sams, R. (2009). Effect of detomidine on visceral and somatic nociception and duodenal motility in conscious adult horses. Veterinary Anaesthesia and Analgesia, 36(2), 162-172. doi: 10.1111/j.1467-2995.2008.00441.x

Guilhen, R. C., Cassu, R. N., Diniz, M. S., Giuffrida, R., \& Duarte, R. R. (2015). A comparison of detomidine in combination with saline, morphine or methadone in horses submitted to experimental oral stimuli. Semina:Ciencias Agrarias, 36(6), 4225-4235. doi: 10.5433/1679-0359.2015 v36n6Supl2p4225

Kaukinen, H., Aspegrén, J., Hyyppä, S., Tamm, L., \& Salonen, J. S. (2010). Bioavailability of detomidine administered sublingually to horses as an oromucosal gel. Journal of Veterinary Pharmacology and Therapeutics, 34(1), 76-81. doi: 10.1111/j.13652885.2010.01193.x

Malone, E., Ensink, J., Turner, T., Wilson, J., Andrews, F., Keegan, K., \& Lumsden, J. (2006). Intravenous Continuous Infusion of Lidocaine for Treatment of Equine Ileus. Veterinary Surgery, 35(1), 60-66. doi: 10.1111/j.1532-950x.2005.00113.x

Mama, K. R., Grimsrud, K., Snell, T., \& Stanley, S. (2009). Plasma concentrations, behavioural and physiological effects following intravenous and intramuscular detomidine in horses. Equine Veterinary Journal, 41(8), 772-777. doi: 10.2746/042516409X421624

McCafferty, D. M., Sharkey, K. A., \& Wallace, J. L. (1994). Beneficial effects of local or systemic lidocaine in experimental colitis. American Journal of Physiology, 266(4), G560-G567. doi: 10.1152/ ajpgi.1994.266.4.g560

Milligan, M., Beard, W., Kukanich, B., Sobering, T., \& Waxman, S. (2007). The effect of lidocaine on postoperative jejunal motility in normal horses. Veterinary Surgery, 36(3), 214-220. doi: 10.1111/j.1532-950X.2007.00255.X 
Nannarone, S., Gialletti, R., Veschini, I., Bufalari, A., \& Moriconi, F. (2007). The use of alpha-2 agonists in the equine practice: Comparison between three molecules. Veterinary Research Communications, 31(Suppl. 1), 30-312. doi: 10.1007/s11259-0070103-7

Rohrbach, H., Korpivaara, T., \& Schatzmann, U. (2009). Comparison of the effects of the alpha- 2 agonists detomidine, romifidine and xylazine on nociceptive withdrawal reflex and temporal summation in horses. Veterinary Anesthesia and Analgesia, 36(4), 384395. doi: 10.1111/j.1467-2995.2009.00466.x

Roscoe, M. P. (2007). Avaliação de seis protocolos de sedação para procedimentos odontológicos em equinos. Belo Horizonte: Universidade Federal de Minas Gerais.

Souza, J. F. F. de, Monteiro, E. R., Campagnol, D., Ramos, R. C., \& Frasson, A. M. F. (2012). Evaluation of nociception, sedation, and cardiorespiratory effects of a constant rate infusion of xylazine alone or in combination with lidocaine in horses. Journal of Equine Veterinary Science, 32(6), 339-345. doi: 10.1016/j.jevs.2011.11.010
Torfs, S., Delesalle, C., Dewulf, J., Devisscher, L., \& Deprez, P. (2009). Risk factors for equine postoperative ileus and effectiveness of prophylactic lidocaine. Journal of Veterinary Internal Medicine, 23(3), 606-611. doi: 10.1111/j.19391676.2009.0311.x

Valverde, A. (2010). Alpha-2 agonists as pain therapy in horses. Veterinary Clinics of North America Equine Practice, 26(3), 515-532. doi: 10.1016/j. cveq.2010.07.003

Yamashita, K., Tsubakishita, S., Futaoka, S., Ueda, I., Hamaguchi, H., Seno, T.,... Muir, W. W. (2000). Cardiovascular effects of medetomidine, detomidine band xylazine in horses. Journal of Veterinary Medical Science, 62(10), 1025-1032. doi: 10.1292/ jvms.62.1025

Zullian, C., Menozzi, A., Pozzoli, C., Poli, E., \& Bertini, S. (2011). Effects of $\alpha 2$-adrenergic drugs on small intestinal motility in the horse: An in vitro study. Veterinary Journal, 187(3), 342-346. doi: 10.1016/j. tvj1.2009.12.015 
